\title{
COMPARATIVE FERTILITY IN THE LOCAL GOVERNMENT AREAS OF ENGLAND AND WALES, 1951
}

\author{
BY \\ WALLIS TAYLOR* \\ Department of Medical Statistics, University of Birmingham
}

In the course of time, the total population of a given area can grow in either or both of only two ways, i.e. by an excess of births over deaths and by an excess of immigrants over emigrants. In England and Wales, virtually nothing is known of internal migration, and estimates made from successive censuses (Taylor, 1950) inevitably can disclose trends alone. In analysing catchment areas for administrative data we may therefore most profitably first look at fertility. Here again sources are meagre, and little is known of the true fertility of sub-areas of England and Wales. Crude birth-rates, the most usual official indices of fertility, are misleading, since they take no account of age-sex structure. Comparison of proportions of children to total population in local government areas is likewise vitiated by two considerations:

(a) they merely reflect the fertility experience of the past decade;

(b) they entirely disregard the effects of emigration and immigration.

Thus a statement to the effect that Newtown $A$ is of inherently high fertility because it has a large annual number of births has no prognosticatory value, since some standardizing procedure to take stock of the age-sex-marital structure is an indispensable prerequisite to legitimate comparison. With that end in view the Registrar-General introduced in 1949 a Comparability Factor designed to compensate for the different age and sex composition of different areas; but we have had little information concerning its derivation. We are told that:

"The Birth Rate area comparability factors and the ratios of the local adjusted birth rates to the national rate shown in columns 9 and 10 of Table $E$ serve a similar purpose to those shown for death rates, as explained in Section 7 below."

After explaining that the use of the factor is to aid comparability, Section 7 refers us to page 5 of the Statistical Review text published in 1938/1939 - or a decade before the birth rate area comparability

\footnotetext{
*In receipt of a Research Fellowship from the Rockefeller Foundation.
}

factor was devised. Little elucidation could therefore be expected or derived from this source. Two new publications, however, have recently changed this picture (General Register Office, 1953, 1954).

With the publication of the Census (ONE per cent. sample) Tables, we have, and for the first time in 20 years, accurate figures referable to populations of local areas, and this makes it possible to compute comparable fertility indices showing the force of fertility in each area. Accordingly, the following Tables show the comparative fertility in 1951 of large areas in England and Wales. Thus the birth rates for each area have been standardized by this indirect method, and the values (England and Wales $=100$ in 1951) are valid measures of the fertility level of each area in that year.

In Table I, legitimate Live-Birth Rates for England and Wales in 1951 are calculated from births given in the Registrar-General's Review and the population estimated at the 1951 Census.

TABLE I

\begin{tabular}{|c|c|c|c|}
\hline \multicolumn{4}{|c|}{ ENGLAND AND WALES 1951} \\
\hline $\begin{array}{l}\text { Age of Mother at } \\
\text { Maternity }\end{array}$ & $\begin{array}{l}\text { No. of Married } \\
\text { Women }\end{array}$ & $\begin{array}{l}\text { Total Legiti- } \\
\text { mate Live } \\
\text { Births }\end{array}$ & $\begin{array}{c}\text { Fertility Rate } \\
\text { per } 1,000 \\
\text { Married } \\
\text { Women }\end{array}$ \\
\hline $\begin{array}{l}15-19 \\
20-24 \\
25-29 \\
30-34 \\
35-39 \\
40-44 \\
45-49\end{array}$ & $\begin{array}{r}61,400 \\
722,900 \\
1,267,200 \\
1,297,300 \\
1,418,000 \\
1,388,700 \\
1,259,500\end{array}$ & $\begin{array}{r}24,299 \\
177,936 \\
211,296 \\
134,592 \\
73,599 \\
21,557 \\
1,479\end{array}$ & $\begin{array}{r}395 \cdot 75 \\
246 \cdot 14 \\
166 \cdot 74 \\
103 \cdot 75 \\
51 \cdot 90 \\
15 \cdot 52 \\
1 \cdot 17\end{array}$ \\
\hline Total & & & $980 \cdot 97$ \\
\hline
\end{tabular}

It is true that the Census Date, (midnight, April $8 / 9,1951$ ), was not located exactly at the centre of the year, but the final rates computed are not affected by this fact; and the Census figures are probably more accurate than the alternative, viz. the Registrar General's mid-year population. We may now apply the rates cited to each local population of married women to ascertain the number of births expected if their fertility rates were those of England and Wales (Table II). 
TABLE II

REGIONS OF ENGLAND AND WALES (NORTHERN REGION)

\begin{tabular}{c|c|c|c}
\hline $\begin{array}{c}\text { Age of Mother } \\
\text { at Maternity }\end{array}$ & $\begin{array}{c}\text { Fertility Rate } \\
\text { in England and } \\
\text { Wales }\end{array}$ & $\begin{array}{c}\text { Married } \\
\text { Women in } \\
\text { Northern } \\
\text { Region }\end{array}$ & $\begin{array}{c}\text { Expected } \\
\text { Births }\end{array}$ \\
\hline $15-19$ & $395 \cdot 75$ & 4,600 & 1,820 \\
$20-24$ & $246 \cdot 14$ & 57,000 & 14,030 \\
$25-29$ & $166 \cdot 74$ & 94,800 & 15,807 \\
$30-34$ & $103 \cdot 75$ & 91,900 & 9,535 \\
$35-39$ & $51 \cdot 90$ & 92,500 & 4,801 \\
$40-44$ & $15 \cdot 52$ & 97,100 & 1,507 \\
$45-49$ & $1 \cdot 17$ & 87,600 & 102 \\
\hline Total & & & 47,602 \\
\hline
\end{tabular}

Actual legitimate births $=51,900$.

Expected legitimate births $=47,602$.

Fertility $=109$ per cent. of average for England and Wales.

Comparison of "expected" births with recorded births now gives us a picture of fertility for each local area compared with England and Wales. The values are summarized in Table III.
The difference between the Registrar-General's figures and those shown in Table III clearly demonstrates the limitations of the crude method. Thus, for example, the West Riding of Yorkshire, which is, in fact, some 6 per cent. below the fertility level for England and Wales, appears by the RegistrarGeneral's method to be 1 per cent. above it. The method here set forth can of course be used for smaller areas than those shown when a reliable estimate of the age, sex, and marital status distribution is available.

\section{REFERENCES}

Taylor, W. (1950). "Birmingham and its Regional Setting". p. 261. British Association for the Advancement of Science.

General Register Office (1953)' 'Statistical Review, Tables, Civil, 1952",p. v. H.M.S.O., London.

p. 131. H.M.S.O., London.

TABLE III

COMPARATIVE FERTILITY RATES FOR 1951

\begin{tabular}{|c|c|c|c|c|c|c|c|c|}
\hline \multicolumn{5}{|l|}{ Region } & \multirow{2}{*}{$\begin{array}{c}\begin{array}{c}\text { Expected Births } \\
\text { (using England and } \\
\text { Wales fertility) }\end{array} \\
644,742\end{array}$} & \multirow{2}{*}{$\begin{array}{c}\begin{array}{c}\text { Actual Legitimate } \\
\text { Births }\end{array} \\
644,758\end{array}$} & \multirow{2}{*}{ Fertility in 1951} & \multirow{2}{*}{$\begin{array}{c}\begin{array}{c}\text { Registrar-General's } \\
\text { Ratio }\end{array} \\
100\end{array}$} \\
\hline England and Wales & . & .. & . & . & & & & \\
\hline $\begin{array}{l}\text { Northern ... } \\
\text { East and West Rid } \\
\text { North-Western } \\
\text { North Midland } \\
\text { Midland .. } \\
\text { Eastern a } \\
\text { London and South } \\
\text { Southern .. } \\
\text { South-Western } \\
\text { Wales .. }\end{array}$ & $\begin{array}{l}\text { dings } \\
\ldots \\
\because \\
\because \\
\text { h-Easter } \\
\because \\
\cdots \\
.\end{array}$ & 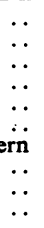 & $\begin{array}{l}\ldots \\
\because \\
\because \\
\because \\
\because \\
\because \\
\cdots\end{array}$ & $\begin{array}{l}\ldots \\
\cdots \\
\cdots \\
\cdots \\
\because \\
\cdots \\
\cdots \\
\cdots\end{array}$ & $\begin{array}{r}47,602 \\
63,885 \\
91,341 \\
52,612 \\
69,709 \\
44,986 \\
159,503 \\
37,464 \\
40,797 \\
36,842\end{array}$ & $\begin{array}{r}51,900 \\
61,250 \\
96,800 \\
51,213 \\
68,318 \\
45,173 \\
148,050 \\
39,190 \\
43,153 \\
39,711\end{array}$ & $\begin{array}{r}109 \\
96 \\
106 \\
97 \\
98 \\
100 \\
93 \\
105 \\
106 \\
108\end{array}$ & $\begin{array}{r}114 \\
103 \\
103 \\
105 \\
103 \\
102 \\
88 \\
103 \\
101 \\
106\end{array}$ \\
\hline 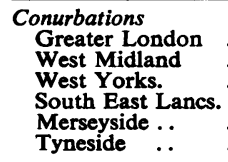 & $\begin{array}{l}. \\
\cdots \\
\cdots \\
.\end{array}$ & $\begin{array}{l}. . \\
\because . \\
\cdots \\
\cdots\end{array}$ & $\begin{array}{l}\because \\
\because \\
\because \\
\therefore\end{array}$ & $\begin{array}{l}\ldots \\
\because \\
\cdots \\
\cdots\end{array}$ & $\begin{array}{r}125,278 \\
35,601 \\
24,751 \\
35,891 \\
19,765 \\
12,925\end{array}$ & $\begin{array}{r}114,035 \\
34,849 \\
24,595 \\
35,707 \\
24,292 \\
13,841\end{array}$ & $\begin{array}{r}91 \\
98 \\
99 \\
99 \\
123 \\
107\end{array}$ & $\begin{array}{r}85 \\
102 \\
100 \\
98 \\
118 \\
109\end{array}$ \\
\hline $\begin{array}{l}\text { Large Administrative } \\
\begin{array}{l}\text { Essex } \\
\text { Kent }\end{array} \text {... } \\
\text { Lancashire } \\
\text { London } \\
\text { Middlesex }\end{array}$ & $\begin{array}{l}\text { Counti } \\
\ldots \\
\ldots \\
\ldots \\
\ldots \\
\ldots \\
\text { ing } \\
.\end{array}$ & $\begin{array}{l}\text { ties } \\
\ldots \\
\cdots \\
\cdots \\
\cdots \\
\cdots \\
\ldots\end{array}$ & $\begin{array}{l}l C i \\
\ldots \\
\cdots \\
\because \\
\cdots \\
\therefore\end{array}$ & $\begin{array}{l}\ldots \\
\because \\
\because \\
\cdots \\
\cdots \\
\cdots\end{array}$ & $\begin{array}{l}24,578 \\
22,576 \\
28,352 \\
52,672 \\
32,756 \\
17,645 \\
25,363 \\
18,195\end{array}$ & $\begin{array}{l}22,431 \\
21,964 \\
28,563 \\
48,790 \\
29,124 \\
17,081 \\
23,934 \\
17,540\end{array}$ & $\begin{array}{r}91 \\
97 \\
101 \\
93 \\
89 \\
97 \\
94 \\
96\end{array}$ & $\begin{array}{r}93 \\
97 \\
96 \\
91 \\
80 \\
83 \\
101 \\
103\end{array}$ \\
\hline
\end{tabular}

